\title{
Unsegregated Municipal Solid Waste in India - Current Scenario, Challenges and Way Forward
}

\author{
Prashant Shukla*†, Pankaj Kumar Sharma*, Shyam Pandey* and V. Chintala** \\ *Department of Mechanical Engineering, University of Petroleum \& Energy Studies, Dehradun, Uttarakhand, India \\ **School of Engineering and Applied Sciences, National Railway Transportation Institute (Deemed to be University), \\ Vadodara, Gujrat, India \\ †Corresponding author: Prashant Shukla; prashantshukla1617@gmail.com
}

Nat. Env. \& Poll. Tech.

Website: www.neptjournal.com

Received: 09-06-2020

Revised: $17-07-2020$

Accepted: $27-08-2020$

Key Words:

Source segregation

Mixed municipal solid waste

Biodegradable waste

Non-biodegradable waste

Recyclable waste

\begin{abstract}
Solid waste management (SWM) is one of the most neglected aspects and becoming a challenge for India as well as other developing nations' environment. India is one of the world's large and fastestgrowing economy. Based on the trends in different nations like the US, China and European countries, it is clear that a developing economy of the nation and population of the country is also playing a vital role in the increasing rate of solid waste generation. Unsegregated waste is the root cause of the inefficient municipal solid waste management (MSWM) systems in India. The existing approach to managing the MSW such as collection, transportation and treatment results in poor utilization of resources. This review paper addresses the current status of MSWM in India. In this paper, various issues and challenges to obtain $100 \%$ source segregated municipal solid waste are also discussed through different cases of urban areas. A way forward through an overview of the municipal waste management policies and practices adopted is being presented in the paper.
\end{abstract}

\section{INTRODUCTION}

Unsegregated municipal solid waste has become a challenging issue not only for India, but even for other developing countries. MSWM (municipal solid waste management) system suffers various problems related to the waste treatment options, i.e. composting or recycling or energy generation (Annepu 2012, Rajkumar \& Sirajuddin 2016). If the existing MSWM system does not offer the solution to these problems, the entire municipal mixed waste will be ended up at dumpsites and therefore causing the MSWM system to be dependent upon landfill sites. A huge amount of dumped MSW (municipal solid waste) is becoming the main reason for groundwater pollution, soil contamination, and environmental pollution. The MSW typically includes domestic and commercial wastes generated in municipalities or notified areas either in solid or semi-solid form (Table 1). It does not include industrial hazardous wastes but includes treated bio-medical wastes. According to data (Table 2), Metro cities are the major contributor in the process of waste generation and due to continuous infrastructure development the production of inert waste is also higher than other regions. Southern region produces larger quantity of compostable waste due to relying on coconut and banana leaves for wide range of applications (Karelia 2019, Priya 2019). Fig. 1 reveals that about $80 \%$ of the total generated waste is being collected by various means while the rest $20 \%$ is again mixed up and lost in the urban environment (Ministry of Housing and Urban Affairs 2019). Out of total waste generated, about $50 \%$ waste is found segregated at the source which is suitable to process further. Hence, out of total generated waste, around $40 \%$ of waste is being processed in the existing MSWM system and the rest of the unsegregated waste is being dumped into landfill sites. Most of the time sorting of waste is done by unorganized sector and from time to time rehearsed by waste producers. Segregation and sorting process takes place in exceptionally dangerous and unsafe conditions and the viability of segregation is sensibly low as unorganized sector segregates just important disposed of constituents from the waste stream which can promise them similarly higher monetary return in the reusing market.

Due to lack of space for inventory many waste processing industries are utilizing the waste from the dumpsite and essentially handle mixed waste which usually gets contaminated. It does not only increase the cost of waste processing but also produces poor quality products such as recyclable contents, compost etc. (Pandey \& Malik 2015, Rawat et al. 2013).

In India, recent solid waste management guidelines 2016 (Lavasa et al. 2016) have made it compulsory to the concerned authority of an area to undertake responsibility 
Table 1: Contents of waste materials in MSW (Sujauddin 2008).

\begin{tabular}{|ll|}
\hline MSW Components & Materials \\
\hline Compostable & Food waste, landscape, and tree trimmings \\
Recyclable & Papers, cardboard, plastics, glass, metals \\
Inert & $\begin{array}{l}\text { Stones and slit, bones and other inorganic } \\
\text { materials }\end{array}$ \\
\hline
\end{tabular}

for all activities related to SWM (Solid Waste Management). These guidelines are applicable beyond the municipal areas also, such as urban cluster, census towns, notified industrial townships, areas under the mastery of Indian railroad tracks, airports, airbase and seaport, defence establishments, special economic zones, state and central government organizations, places of the pilgrimage, religious and historical importance etc. Despite all the positive moves put up by the Government of India, the current status of the Indian MSWM system is not satisfactory.

\section{Existing Solid Waste Management Strategies}

As per the SWM guidelines 2016 (Lavasa et al. 2016) waste generator has to identify the category of waste and keep it separately i.e. source segregation. This is the key function

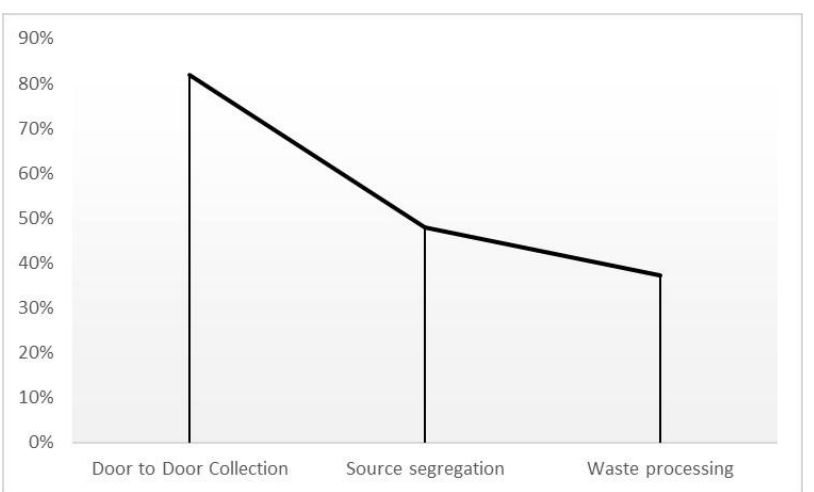

Fig. 1: MSWM practices in Indian cities. at the root level of MSWM process, which redirects the right type of waste to its right place. Therefore to get $100 \%$ source segregated waste, Govt. has started various awareness programs through social media, television, newspaper etc. Few megacities like Bengaluru, Indore and many others have implemented a fine system for observing no source segregation of solid waste (Akshatha 2018). Once the MSWM system receives all the 3 categories of segregated waste, it is processed for its treatment and the only inert is dumped into landfill sites. Common treatment techniques are recycling of plastics, composting and waste to energy.

The combination of waste treatment methods with MSWM makes an IMSWM (integrated municipal solid waste management) system (Fig. 2). It is being followed by most of the developed countries because its advantageous principle maintains the correct flow of segregated waste and does not allow it to be on the dumpsite (Planning Commission 2014).

Even if there is no source segregation a sustainable waste management system is supposed to handle the mixed waste. Therefore many countries have already moved a step ahead by introducing advanced waste to energy plants such as plasma arc recycling. It involves heating waste to super-high temperatures to produce gas that can be burned for energy and rocky solid waste that can be used for building (Woodford 2019). This process does not involve combustion like a conventional incineration process. Instead of only burning the waste (at a few hundred degrees), the waste is heated at higher temperatures (thousands of degrees) so it gets melt and then vaporizes. This process is performed by the plasma arc method, which is a kind of super-hot "torch" made by passing gas through an electrical spark.

\section{Current Scenario of Unsegregated Waste and Failures in MSWM System in India}

With an increasing population, MSW management in the country has come into view like a serious problem not only due to environmental and esthetic issues but also due to the sheer quantities produced every day.

Table 2: Composition of MSW in India and its regional variation (Annepu 2012).

\begin{tabular}{|c|c|c|c|c|c|}
\hline \multirow[t]{2}{*}{ Region/city } & \multirow[t]{2}{*}{ MSW (TPD) } & \multicolumn{4}{|c|}{ Compositions of MSW } \\
\hline & & Compostable (\%) & Recyclables(\%) & $\operatorname{Inert}(\%)$ & Moisture (\%) \\
\hline Metros & 51402 & 50.89 & 16.28 & 32.82 & 46 \\
\hline Other cities & 2723 & 51.91 & 19.23 & 28.86 & 49 \\
\hline East India & 380 & 50.41 & 21.44 & 28.15 & 46 \\
\hline North India & 6835 & 52.38 & 16.78 & 30.85 & 49 \\
\hline South India & 2343 & 53.41 & 17.02 & 29.57 & 51 \\
\hline West India & 380 & 50.41 & 21.44 & 28.15 & 46 \\
\hline Overall Urban India & 130000 & 51.3 & 17.48 & 31.21 & 47 \\
\hline
\end{tabular}


Hence the government of India is driving various awareness campaigns with the help of NGOs and some agencies like Shuddhi, Vatvaran, Ruchi, etc. for the efficient performance of the MSWM system. These campaigns are promoting various positive activities like zero or minimum waste generation, segregation of waste at source, lesser use of the non-recyclable and non-degradable substances through social media, print media and TV channels, etc. These efforts have shown remarkable improvements in a few cities like Indore, Ambikapur, Mysuru and Tirunelveli. In these cities, residents have started showing their interest towards source segregation, because either local urban body fines for non-segregation of waste at source or on the positive side new startups of recycling and composting (such as Saahas

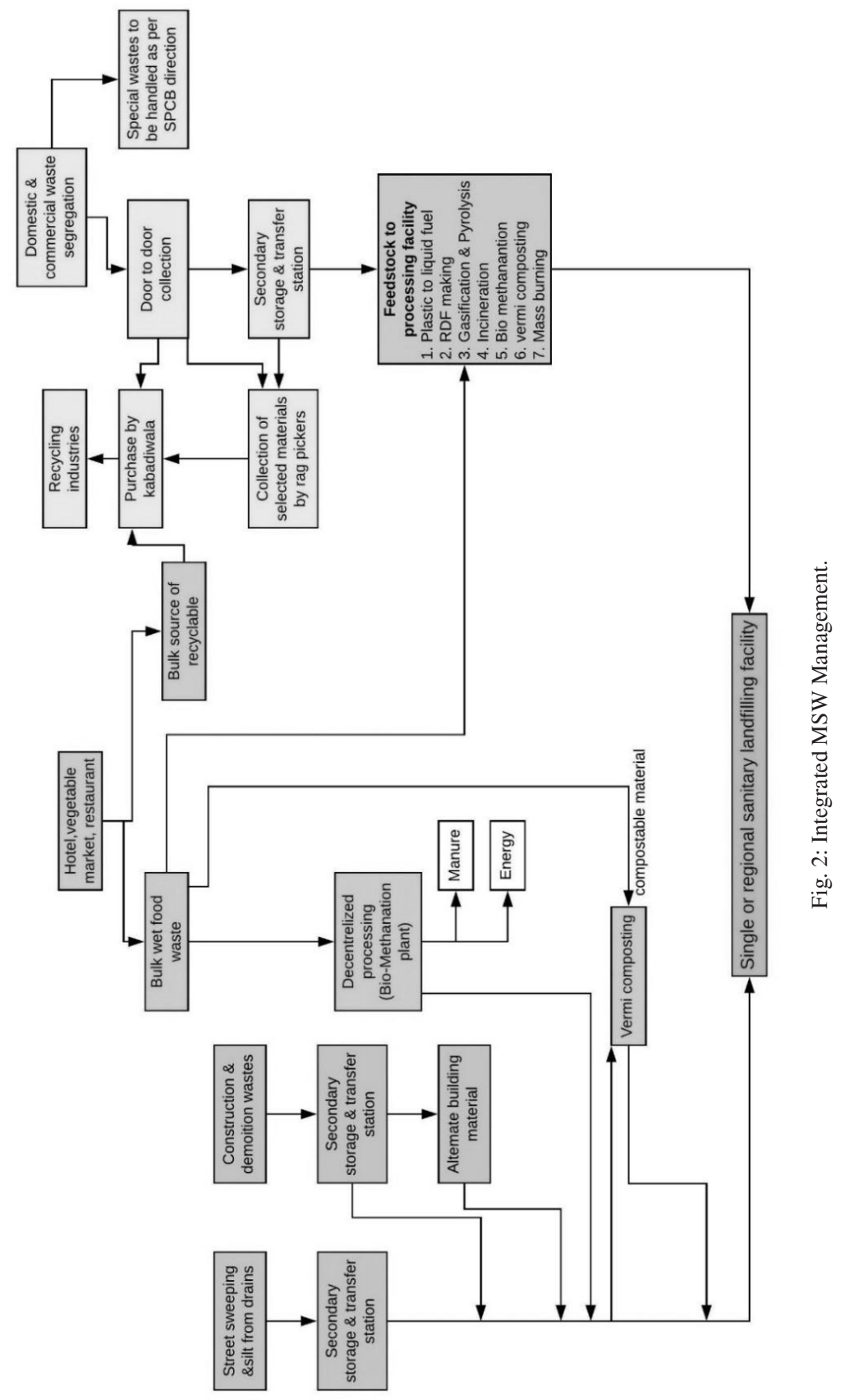




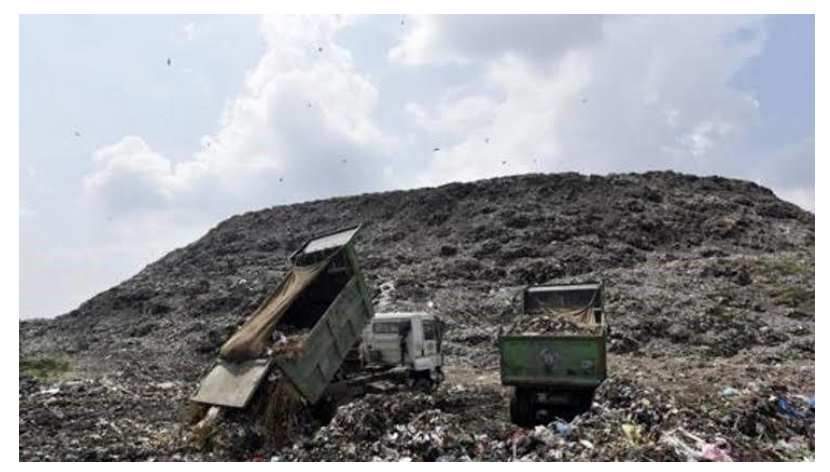

Fig. 3: Trucks dumping garbage at Ghazipur Landfill site in New Delhi, India

Zero Waste, Hasiru Dala, Namo E-waste, GEM Enviro Management, Citizengage, Paperman, Vital Waste, Extra Carbon, etc.) are rewarding for segregating the recyclable and non-recyclable waste at a source point and depositing the garbage at a predefined location. These ideas are helping to minimize the open dumping of MSW (Dash 2017, Manohar 2019, Rai 2017, Subramanian 2017).

Despite all these positive moves and promotions, the major portion of India is still facing many problems related to solid waste such as lack of land space for dumping MSW, spilt out waste on roads, poor quality of compost due to the presence of plastic and metals. Segregation at source, collection, transportation, processing and scientific disposal of waste is not sufficient and leading to the degradation of the environment and poor quality of life. Some key issues are affecting proper management of MSW such as limited primary collection at the doorstep, reluctance in public to take ownership, unavailability of adequate funds, lack of access to technical exposer and unscientific disposal of MSW at dumpsites (CPCB 2018, Lahiry 2017, Lavasa et al. 2016, Press Trust of India Ltd. 2019).

Ghazipur landfill can be a relatable example of such a scenario (France-Presse \& Agence 2019), this site has already taken about 40 football pitches of land on the eastern edge of New Delhi (Fig. 3), which is widely recognized to be the world's most polluted capital. The vast dump of waste rises by $10 \mathrm{~m}$ every year. It is already $65 \mathrm{~m}$ high and will be taller than the $73 \mathrm{~m}$ Taj Mahal next year.

Fig. 4 represents the current practice of MSWM in India (Ministry of Housing and Urban Affairs, 2019), where around $82 \%$ of waste is collected by the door to door pick up or by community bin, and around $48 \%$ of waste is found in segregated manner i.e. source segregated. Therefore only $37 \%$ of waste can be processed for further treatment like composting, WTE or recycling. The remaining amount of un-segregated waste is directly dumped into landfill areas.

\section{Failure of Solid Waste Management Projects in India}

In Shrinagar, India, J\&K Municipal Corporation (SMC) has failed to segregate waste at source in the summer capital (Yaqoob 2018). It has also not received individual garbage dustbins at sources as Solid Waste Management Rules

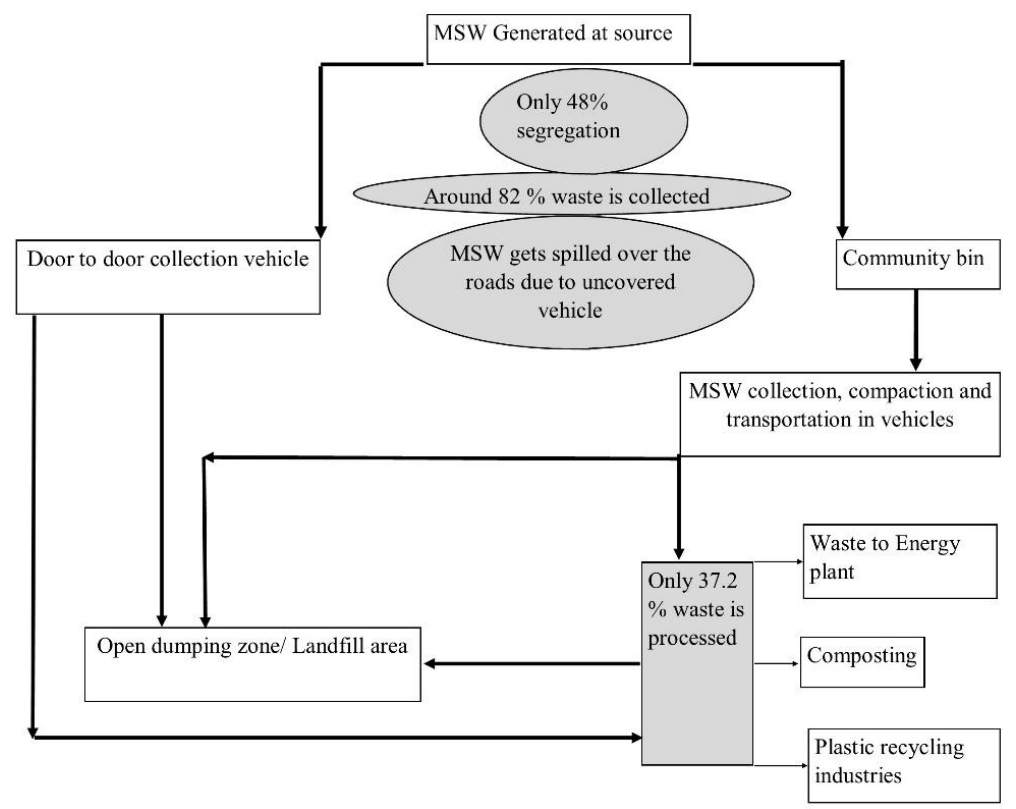

Fig. 4: Process flow of MSWM n India. 
(SWMR) are yet to be enforced. The SMC began waste separation as a pilot project last year in many districts, such as Sanat Nagar. After segregating garbage collected from households, the SMC used to again mix the waste. Therefore, the segregation at the source served no purpose.

The aspiring source segregation program organized by the civic bodies in Delhi (Vibha et al. 2017) has failed to achieve desired results. After the 4 months of this initiative, very few changes in the situation have been observed on the ground. Residents complained that in the absence of adequate supervision and control by authorities, the initiative was running out of steam. The north and east Delhi civic bodies had started the source segregation program at 10 selected neighbourhoods on the occasion of World Environment Day. The motive behind this project was to motivate the people to sort out their domestic trash. The initiative was designed to set up model colonies to demonstrate the introduction of the 2016 Centre's Solid Waste Management Rules. The agencies were expected to disseminate bins, run awareness drives, and engage vehicles with partitioned cabins for collecting bio-degradable and non-biodegradable waste.

However, after four months, residents in the areas continued to dump waste without segregating them. Similarly, after the launch of the source segregation campaign in the north and east Delhi (Vibha et al. 2017) local urban bodies have also been unable to acquire enough vehicles for disposing of source segregated waste. The project initiated with a series of introductory workshops educating the public about the value of source segregation of waste. However, after two interactions, the north municipal officials became unreachable. Vehicles assigned to collect dry and wet waste disappeared too. It was also observed that the sanitation workers coming to collect garbage rarely help the residents in emptying the contents of the garbage bins into the vehicles (tippers). It is also reported that the height of the tipper is too much for any individual man or women to reach. A major proportion of the garbage litters on the road, while one try emptying the contents on to the tippers. Once it is dumped into the tippers, the dry and wet waste gets mixed, then there is no meaning of segregating waste at the source.

In Bengaluru (Harshtha \& Nisar 2019), door-to-door garbage pickup from small apartments and unorganized residential areas across the city has been tangled. Reason: collectors come for a very small time, while residents have no systematic plan to keep the solid waste segregated and ready to be picked up. Many residents complained that their entire effort towards segregation and collection turns nothing when the garbage collection system does not meet the schedules. Even though residents keep the waste segregated, the garbage collectors dump them altogether. This results in a lack of interest among residents to segregate. The BAF (Bengaluru apartment federation) provides a solution that fits well over thousands of flats: segregate the garbage, place them at a central point from where the sanitation workers pick it at the time of their choice. In the same city, a new and innovative step has been taken to tackle the MSW. A not for a profit think tank in Bangalore named PAC (Public Affairs Center) (Nagendra et al. 2019), launched a mobile app "PAC Waste Tracker" which works on citizen science and visual mapping to find out the various issues affecting the waste collection mechanism in the city. This pilot project implemented in the four wards, which has recorded the issues coming at each collection point. Such challenges have been reported for a total of 9 months including non-segregation of waste, inconsistent waste collection, collection annoyance and non-compliance.

Agra, classified as one of India's most polluted cities (Lavania 2018), transports tons of waste in open lorries daily on city roads to the Kuberpur sites. As the trucks ply, loads of garbage spill over the sides. Some of these even get dropped on commuters and cars alike. These trucks have only added to Agra's pollution levels. the civic authority has not been able to ensure modern vehicles for the storage and disposal of the Civic Solides (MSW) even after strict directions have been given by the NGT (National Green Tribunal) to Agra Municipal Corporation. According to officials, the civic body trucks collect around 500 metric tonnes of garbage from various parts of the city every day and transfer it to the Kuberpur site. According to norms, these vehicles must be covered both from the rear and topsides. But around $40 \%$ of these vehicles run without covers. The back of many of these trucks is damaged, causing more spillage.

Similar issues have been identified in two major cities of Uttarakhand, i.e. Dehradun and Haridwar (Sharma 2018), where uncovered vehicles were used for transporting waste. Out of the total available vehicles, only $58 \%$ and $64 \%$ of vehicles were operational in Dehradun and Haridwar, respectively. Further, only $7 \%$ and $46 \%$ of vehicles were covered in Dehradun and Haridwar. Authors reported that inefficient transportation has become another reason for floating garbage in Kolkata city (Hazra \& Goel 2009). Poor route planning, lack of information about collection schedules, poor roads and numbers of vehicles for waste collection drastically affects the process of MSWM.

\section{Quantitative Analysis of Performance of Indian MSWM Systems}

As per the latest report of the CPCB (Central Pollution Control Board), published in February 2018, the total quantity of waste generated in the country is estimated at 
around 43298.385 tons per day. Out of which, 45082.15 tons is being collected and the remaining $18 \%$ is littered. Out of the total collected waste, only 15386.81 ton is being treated and remaining 22904.70 tons is being disposed of (Sambyal \& Agarwal 2018). A standard MSWM system has two basic functions i.e. collection and segregation. The following data highlights the current scenario of collection \& segregation under the Indian MSWM system.

In India, every state has around 84000 wards and $3 / 4^{\text {th }}$ of these wards have successfully adopted door to door waste collection system. But without a proper waste disposal system, such an effort is not meaningful (Jadhav 2018). Municipal bodies in Maharashtra generate maximum garbage, i.e. 22,570 MT daily, then Tamil Nadu (15,437 MT), Uttar Pradesh (15,288 MT), Delhi (10,500 MT), Gujarat (10,145 MT) and Karnataka (10,000 MT) (Jadhav 2018). These data reflect that the municipal bodies of the abovementioned states are dumping such a big amount of waste on to their landfill sites, which are actually beyond their capacity to handle, hence it is polluting the surrounding land, groundwater and air. According to the Delhi-based Centre for Science and Environment (CSE), cities are now lacking for land space where they can dump their waste. This scenario is leading them to throw it in the 'backyards' of smaller towns, suburbs, and villages.

It is found that only 8 out of 35 states have the practice of processing more than half the daily garbage generated in their cities, hence not one has achieved $100 \%$ processing (Jadhav 2018). Jharkhand, Bihar, Odisha, Andhra Pradesh, Tamil Nadu, Haryana, West Bengal, Jammu \& Kashmir do not process even $10 \%$ of their MSW, while Arunachal Pradesh and Dadra \& Nagar Haveli do not have the practice of processing their waste (Jadhav 2018). There are only four states that process more than $60 \%$ of municipal waste. In this list, Chhattisgarh comes first, where almost $74 \%$ of waste is processed. Then this legacy is followed by Telangana (67\%), Sikkim $(66 \%)$ and Goa $(62 \%)$. Delhi processes $55 \%$ of its daily garbage (Jadhav 2018).

Fig. 5 (The World Bank 2018) shows the comparative data between MSW collection and its treatment in major Indian cities. According to these data, the Indian MSWM system is collecting a major proportion of waste (i.e. around $82 \%$ ) from door to door collection service, then half of the collected waste is being treated because the collected waste is not completely segregated at source. Among all the major cities in India, Hyderabad, Kochi, Pimpri, Kanpur, Ahmedabad, Coimbatore and Mumbai can treat their entire collected waste. It has become possible, these cities have started maintaining all the possible ways of treatment of waste. Such as in Kanpur, there is a plant to process 1500 tonnes per day capacity of solid waste was set up with a tipping platform, a pre-segregation unit, a composting unit, an RDF (Refuse Derived Fuel) unit, a plastic segregating unit, a briquette manufacturing unit, and a secured landfill in place (Goel 2017).

Similarly in Hyderabad, The GHMC (Greater Hyderabad Municipal Corporation) has done some good work in the solid management system, i.e., segregation of dry and wet waste at the source itself by involving residential welfare associations, NGOs, self-help groups and citizens. Through this, the collection of garbage has increased from 3,000 tonnes to 4,800 tonnes daily basis. Whereas Rudrapur, Cuttack, Kota, Amritsar, Leh, Vishakhapatnam, Bhubaneshwar are failed to treat their waste. Table 3 shows the MSWM and related facilities available in major Indian states. Among all the mentioned states Tamil Nadu has a higher number of waste treatment facilities whereas Orissa and Uttarakhand do not have any facility to treat their solid waste. All these data reflect that only $36 \%$ of states in India are having treatment plant, and due to the unavailability of the desired form of waste (segregated waste) some of them like in Maharashtra, Delhi, Gujrat, Tamil Nadu are not able to perform at its maximum capacity. Hence, the mixed waste is being dumped in open land areas and getting stockpiled (Kumar et al. 2017, Ministry of New and Renewable Energy 2016).

\section{Problems Associated with Unsegregated Waste}

As is discussed in the previous section that the unsegregated waste is not easily acceptable by the waste processing industry therefore it gets dumped into the landfill sites. Subsequently, this practice is promoting the improvement of new sanitary landfills or extension of an existing landfill in different urban areas in India (Moghadam et al. 2009). Landfill practice caused many accidents in history (Doshi 2016, Manohar 2017, TNN 2018) like landfill fire in Delhi and West Bengal, landfill sliding in Addis Ababa (Ethiopia) $\&$ Shenzhen (China), etc. Hence, when mixed waste is ended to landfill sites it brings out many other issues such as landfill fires (Lee et al. 2018), landfill sliding (Pulat et al. 2017), environmental impact due to food waste (Tonini et al. 2018).

Apart from environmental issues, mixed waste has become the main cause of the poor performance of waste processing industries like WTE, composting or plastic recycling industries. Many WTE plants in the country are either combustion-based or gasification based. Combustion based plant requires a dry form of waste and wet for gasifier based plants. But due to the unavailability of the required form of segregated waste, most of the WTE plants are in the "Not Working" condition (Sharholy et al. 2008). 


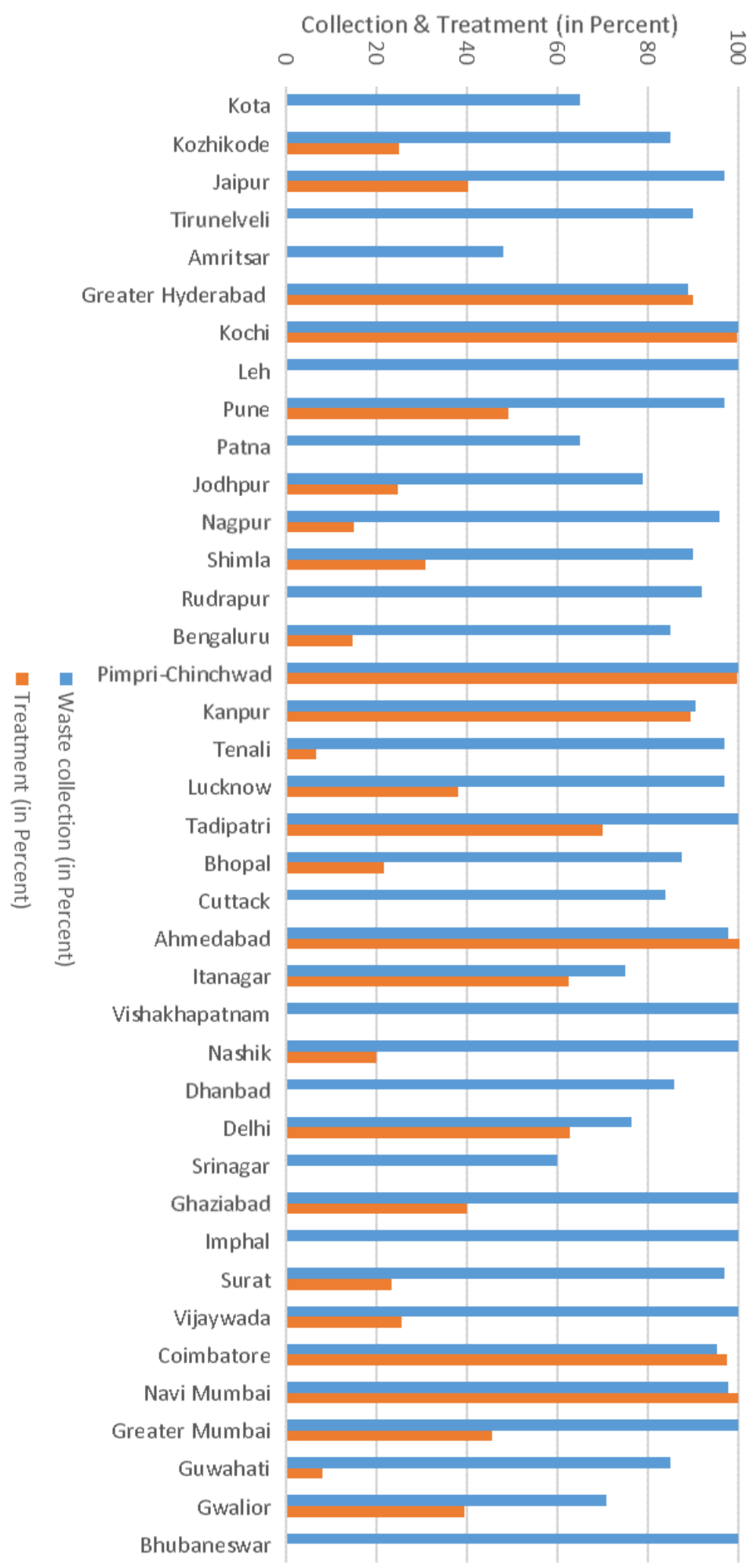

Fig. 5: Collection Vs. Treatment in major Indian cities. 
Table 3: Facilities for MSWM in major Indian states (Ministry of New and Renewable Energy, 2016).

\begin{tabular}{|c|c|c|c|c|c|c|}
\hline \multirow[t]{2}{*}{ S. No. } & \multirow[t]{2}{*}{ States } & \multicolumn{5}{|c|}{ No. of Units for treatment } \\
\hline & & Composting & Vermicomposting & Biomethenation & Pelletization & Waste to Energy \\
\hline 1 & Andhra Pradesh \& Telangana & 24 & 0 & 0 & 11 & 2 \\
\hline 2 & Andaman\& Nicobar & 1 & 0 & 0 & 0 & 0 \\
\hline 3 & Chandigarh & 0 & 0 & 0 & 1 & 0 \\
\hline 4 & Delhi & 3 & 0 & 0 & 0 & 3 \\
\hline 5 & Goa & 14 & 0 & 0 & 0 & 0 \\
\hline 6 & Gujrat & 3 & 93 & 0 & 6 & 0 \\
\hline 7 & Himachal Pradesh & 10 & 0 & 0 & 0 & 0 \\
\hline 8 & Karnataka & 0 & 0 & 0 & 0 & 0 \\
\hline 9 & Kerala & 21 & 7 & 10 & 1 & 1 \\
\hline 10 & Madhya Pradesh & 7 & 0 & 0 & 2 & 0 \\
\hline 11 & Maharashtra & 6 & 2 & 5 & 5 & 2 \\
\hline 12 & Orissa & 1 & 0 & 0 & 0 & 0 \\
\hline 13 & Punjab & 1 & 3 & 0 & 0 & 0 \\
\hline 14 & Rajasthan & 0 & 0 & 0 & 0 & 0 \\
\hline 15 & Tamilnadu & 102 & 24 & 0 & 3 & 0 \\
\hline 16 & Uttarakhand & 0 & 0 & 0 & 0 & 0 \\
\hline 17 & Uttar Pradesh & 0 & 0 & 0 & 0 & 0 \\
\hline 18 & West Bengal & 13 & 7 & 0 & 0 & 0 \\
\hline
\end{tabular}

Similarly, the majority of MSW compost produced in Delhi is not able to meet quality control guidelines of fertilizer control order standard (Mandal et al. 2014). Fertilizing index values of MSW compost was satisfactory, whereas clean index values were much below the desired value due to the presence of plastics \& excess heavy metals in the compost which may come through many sources like electronic and electrical waste. The chances of availability of plastic and heavy metals in compost are increased when mixed waste/partially segregated waste is processed in the compost plants. Even if there is a practice of source separation, bio-degradable waste still contains some contaminants which may affect the treatment process and impact the quality of the compost (Jank et al. 2015). Contaminants can be present in the separated bio-degradable waste, it is because segregation of bio-waste is not always done in a correct way, such as the collection of segregated waste in plastic bags causes contamination of biowaste. Such products cannot be sold in the market at a competitive price hence affect the financial viability of the project. Whereas mixed waste causes wear and tear in the waste handling equipment and when it is combusted it becomes a source of emission of toxic pollutants (Rawat et al. 2013, Malcolm Richard et al. 2011, Mandal et al. 2014). It is also observed that in India, sorting of waste is done by rag pickers, who manually pick up waste from the roads and dumping zones which can be recycled and re-used. Hence, they are exposed to health damage and infection while manually sorting the waste without any protection. Furthermore, it has to be segregated either manually or mechanically in addition to the manual segregation. It is a time-consuming process to segregate the useful waste out of total random mixed waste. Apart from rag pickers, the segregation of waste is largely fulfilled by the unorganized sector and infrequently practised by waste producers (Pandey \& Malik 2015).

It is also reported that (Hindu 2012) the plastic waste on either on dumpsite or streets, roads and community bin chokes the stormwater drainage system. As per the report, the dumping of garbage in water bodies has been increasing the decay of lakes and ponds in the southern suburbs of Chennai. Because residents are releasing sewage and dumping plastic and other waste in channels linking water bodies and stormwater drains. Therefore every single stormwater drain and channel in the city, which connects one lake with the other has been nearly ruined. People find it easiest approach to throw waste outside their homes through windows directly into these drains and water channels. A huge amount of floating garbage is observed in such drains all over the southern suburbs of Chennai.

Hence, proper segregation of waste leads to scientific disposal of waste and on the other hand recyclables could be directly sent to recycling units (Sharholy et al. 2008, 
Shwetmala et al. 2011). It can lead to various benefits such as enabling technology up-gradation, better quality products, saving of valuable raw material resources of the country, reducing the need for landfill space. Therefore various methods have been intervented into the MSWM system to get segregated waste and its further treatment.

\section{Significant Challenges for the Process of Source Segregation}

In many developing countries including India, residents response towards the segregation of waste is affected by the partial involvement of residential community, real estate developers, other residents, and charges involved in MSWM (Agbefe et al. 2019, Speier et al. 2019, Basnayake et al. 2019). It is reported (Planning Commission 2014, Rawat et al. 2013) that the waste that is generated in the country is a mixed waste comprising a large amount of inert material and a very high moisture level unlike in other countries. A high level of moisture and inertness in the waste creates problems to derive power from it. The Govt. of India took the initiative to increase awareness amongst the public through SBM (Swachh Bharat Mission) (Agarwal 2018), and the all India segregation campaign was launched on June 5, 2017. The main objective of this campaign is to ensure, cities must design a mechanism through which 100 per cent source segregation can be done within one year, which is a challenge and yet has been a game-changer wherever implemented properly. According to the CPCB report, 2018 there is no proper public system of primary collection from the source of waste generation and municipal sanitation workers collect waste primarily through street sweeping, etc. Also, there is no practice of sorting waste at source in a scientific way except few places like Indore, Tirunelveli, Goa, Chandigarh, where source segregation is under regular practice (CPCB 2018). As per SBM August 2018 data (Agarwal 2018), 43\% of the total wards in the country are segregating their waste at source. In 2017, door-to-door collection coverage increased from $53 \%$ to $80 \%$.

As per the SWM rules 2016, waste must be segregated into different disposal bins with different colour codes for biodegradable. However, most of the source location like slum areas, which belongs to lower socio-economic condition, does not have enough space to occupy different disposal bins. Hence, the waste collected at the source point is in the mixed form and it moves from source to primary location, primary to secondary location then landfill sites as it is ( $\mathrm{Pa}-$ dilla \& Trujillo 2017). Therefore, the author has concluded through a survey that source segregation is affected by SEC (socio-economic conditions). As per the survey higher SEC gives a higher rate of source segregation whereas lower sections are the major representative of the population of any developing country. SEC has also affected the collection coverage of MSW, according to reports of CPHEEO (Central Public Health and Environmental Engineering Organisation) and CPCB (Central Pollution Control Board) (Mandal 2019), collection coverage in the peri-urban or slum areas is low compared to commercial or high-income group or middle-income group areas.

Many of the cities in India have a limited practice of segregation (Agarwal 2018) through the distribution of blue and green dustbins. At present, the majority of urban and metro housing societies/communities are facilitated with three different bins of different colours for collecting waste like biodegradable, non-biodegradable and domestic hazardous waste, thus it requires time and effort for segregations of waste. Whereas there are inadequate treatment techniques and facilities for the transportation and disposal of segregated MSW. These factors affect the willingness of residents towards source segregations.

In addition, the efficiency of a solid waste collection system depends on the type of vehicles, its capacities and the number of staffs. The collection system is classified into two categories, i.e., door-to-door collection and communal collection. Door to door collection system generally exists in societies those who are willing to pay whereas in slums and low-income areas are covered under the communal collection system. In many cities (Agarwal 2018), the collection of source segregated waste has started but to lack of facilities, mixed waste ends up in the dumpsite. Such as, in Tirunelveli, a city in Tamil Nadu awarded by the government for achieving 100 per cent source segregation, residents segregate only recyclable plastic and handover it to the collector on predefined days. Whereas mixed waste is collected daily, however SWM Rules, 2016 mandate that waste must be segregated into wet, dry and domestic hazardous at the source itself.

\section{Way forward by the Government of India}

To make the existing MSWM system more efficient and for the optimum utilization of the resources Govt. of India has given the following recommendations (CPCB 2018):

(i) At the central level, a technical cell must be formed to help the state urban development department and local bodies to enable them for the execution of SWM Rules, 2016.

(ii) For proper implementation of SWMR, 2016, every State should display strategy \& time-targeted action plan, which should be displayed on their website. Every state should have a cell to assist local bodies in terms of evolving plans and policies to provide technical and financial assistance. 
(iii) Every State/UT should follow the guidelines for designating the landfill site and setting-up of a shielding zone around the landfill and waste processing sites.

(iv) State Pollution Control Boards to take-up with the local urban bodies and suggest setting up of waste treatment facilities either by themselves or by private entrepreneurs.

(v) Ministry of Environment \& Forest should have a closer look at the matter of execution of SWMR, 2016 with Chief Secretaries/ Chief Ministries of the States/UTs.

(vi) Segregation of waste at source is to be made compulsory for having safe disposal of MSW. The wet/biodegradable waste should be converted into compost and dry waste should be recycled/recovered

(vii) If recycling is not done, then the dry waste must be transported to cement kilns for co-processing.

(viii)Every local body is supposed to submit a time-targeted work plan for the implementation of the SWM Rules, 2016, in cities/ towns.

(ix) The status of the implementation of solid waste management rule, 2016, must be reviewed regularly by the secretary to get satisfactory results.

\section{Success Story of Indore Municipal Corporation (IMC), India- A Case Study}

Indore city is situated in Indian state Madhya Pradesh over the area of $275 \mathrm{~km}^{2}$ with a population density of 10000 $\mathrm{P} / \mathrm{km}^{2}$. There are around 6.20 Lac household and commercial places, which are the main sources of MSW generation. Being an urban area, the quantity of MSW is also being increased every year along with its population. As per the observation quantity of MSW since 2001, has been increased from 617 MT/Day to 1115 MT/Day till now. Such a rapid increase in the quantity of MSW has become a challenging task for local urban bodies. Hence a survey was conducted in September 2015. Presentations were made to the commissioner and mayor-in-council. which reported the following observations ("A2Z to restore garbage" n.d.; Bhargava n.d.; "Indore: Converting solid waste into electricity still a distant dream | Free Press Journal," n.d.; "The Curious Case of a Clean Clean Indore- Business News," n.d.):

(i) There were around 1380 garbage containers, which were old and dilapidated. Even in posh residential and more upmarket areas, there would usually be open garbage spots either in empty plots. Likewise around 480 open spots were identified where waste was being dumped and burnt.

(ii) It was observed that cleaning staffs were a bit reluctant towards supervision and management of allotted tasks, which causes littered waste on sites, road, and streets.

(iii) It was found the number of machinery used for waste management operation was not sufficient and it was not properly maintained.

(iv) Using landfill sites was not under the practice to dump the MSW.

(v) There was no door to door waste collection facility, which brings a neutral response in public towards waste management.

On the basis of the above observations, some revolutionary steps have been decided to initiate such as ("A2Z to restore garbage" n.d.; "How Indore Became Garbage-Free" n.d.; "Indore: converting solid waste" n.d.; "Smart City Indore" n.d.; "The Curious Case" n.d.):

An integrated MSWM has been introduced which has a predefined solution of MSW from collection to its treatment $\&$ disposal. It starts from door to door collection of solid waste through vehicles, equipped with different chambers for segregated waste.

(i) A mechanized road and street sweeping have been initiated, which helps to prevent littering of waste. Whereas manual picking of littered waste has also become the routine task under MSWM.

(ii) Construction and demolition debris is being collected separately.

(iii) Small composting units have been deployed.

(iv) Special units have been established for the treatment of plastic waste.

(v) A system was formed to penalized if anyone is found littering.

(vi) Treatment facility for biomedical waste like Incinerator (capacity of $300 \mathrm{Kg} / \mathrm{Hr}$ ) has been installed.

(vii) Twin litter bins have been installed in all commercial areas.

(viii)Two dustbins became compulsory in the household for ensuring source segregation.

(ix) Stray cattle/pigs have been removed from the city.

(x) Established 9 modern transfer stations facilitated with the following advancement:

- The cylindrical design of the storage to prevent the surface from corrosion.

- Hydraulic compactor with a capacity of 15 MT.

(xi) Two scientific landfill sites of 6.25 acre each have been brought into operation.

(xii) Bioremediation of 2 Lakh MT old waste is being done in the area of 5 acres. 
(xiii)A concrete road with the drainage facility has been brought into service.

Indore through its commendable collaborative efforts has achieved $100 \%$ segregation of waste at source and door-todoor garbage collection. The cleanliness scenario of Indore was changed by the improved habits of its people. Within one year the Municipal Corporation successfully sensitized citizens for segregation at source and not dumping garbage in open areas. The cleanliness story of Indore is a true transformation through community participation. Therefore according to Swachh Survekshan 2018 Results ("Swachh Survekshan" n.d.) Indore has been declared the cleanest city in India. Madhya Pradesh's capital Bhopal ranked as India's second cleanest city for two years in a row. Chandigarh is the third cleanest city.

\section{RECOMMENDATIONS AND CONCLUSIONS}

Various reports, research papers and news articles show that the un-segregated waste has affected the environment at its extreme and it is continuously causing many problems in the field of MSWM in India. Hence, there is an urgent need for proper segregation of waste that would lead to scientific disposal of waste. It can lead to various benefits such as enabling technology up-gradation, better quality products, saving of valuable raw material resources of the country, reducing the need for landfill space. Every citizen in India should be encouraged to keep segregated bins for wet, dry and hazardous waste and stop littering on the streets and segregation of waste should be made mandatory. Apart from adopting these habits, improving waste collection efficiency and developing suitable technologies for waste segregation, transportation, treatment, and disposal could be a step towards the solution of this problem. Besides, there should be an efficient mechanism for the segregation of waste at the source as it has become a herculean task all over the country. Also, there is a need to have a proper policy and cost-effective technological support for WTE Sector as existing technologies do not seem to be compatible with local requirements. Whereas a mechanized segregation system can also be introduced at primary or secondary storage, in which mixed MSW will be dumped and segregated in different categories such as compostable, non-compostable and recyclable waste. This system can be an effective intervention for the existing MSWM system and will be helpful to increase the segregation rate especially at high MSW producer location like institutions and commercial areas.

\section{ACKNOWLEDGMENT}

This paper is an outcome of a SEED funded project, Project Id: UPES/R\&D/07022019/01, supported by the University of Petroleum and Energy Studies (UPES) Dehradun, Uttarakhand, India.

\section{REFERENCES}

A2Z to restore garbage processing plant in Indore in 15 days. (n.d.). Hindustan Times. Retrieved October 8, 2018, from https://www. hindustantimes.com/indore/a2z-to-restore-garbage-processing-plantin-indore-in-15-days/story-B1IeevhPMLNQkcilpwDrNP.html

Agarwal, S. S. S. 2018. Is Swachh Bharat Mission ensuring waste segregation systems? Retrieved June 15, 2019, from Down to Earth website: https://www.downtoearth.org.in/blog/waste/is-swachh-bharatmission-ensuring-waste-segregation-systems--61885

Agbefe, L. E., Lawson, E. T. and Yirenya-Tawiah, D. 2019. Awareness on waste segregation at source and willingness to pay for collection service in selected markets in Ga West Municipality, Accra, Ghana. Journal of Material Cycles and Waste Management, 0(4): 905-914. https://doi. org/10.1007/s10163-019-00849-x

Akshatha, 2018. Not segregating waste? BBMP mulls hefty fine - The Economic Times. Retrieved January 21, 2020, from Economic Times website: https://economictimes.indiatimes.com/news/ politics-and-nation/not-segregating-waste-bbmp-mulls-hefty-fine/ articleshow/65588209.cms?from $=\mathrm{mdr}$

Annepu, R. K. 2012. Sustainable Solid Waste Management in India. Columbia University, New York, 2(01).

Basnayake, B. F. A., Popuri, S., Visvanathan, C., Jayatilake, A., Weerasoori, I. and Ariyawansha, R. T. K. 2019. Concerted initiative for planned management of municipal solid waste in target provinces in Sri Lanka. Journal of Material Cycles and Waste Management, 21(3): 691-704. https://doi.org/10.1007/s10163-018-0815-5

Bhargava, Anjuli (n.d.). How Indore Became Garbage-Free and Beat Every Other City to It. Retrieved June 24, 2019, from https://www. thebetterindia.com/114040/indore-madhya-pradesh-clean-garbagefree-india/

CPCB, 2018. CPCB Annual Report as per MSW Rules, 2016.

Dash, D. K. 2017. Solid waste management: Tirunelveli first to have $100 \%$ waste segregation | India News - Times of India. Retrieved May 21, 2019, from Times of India website: https://timesofindia. indiatimes.com/india/tirunelveli-first-to-have-100-waste-segregation/ articleshow $/ 57485885 . \mathrm{cms}$

Doshi, V. 2016. The Kolkata dump that's permanently on fire: "Most people die by 50" | Cities | The Guardian. Retrieved September 27, 2018, from The Guardian website: https:/www.theguardian.com/ cities/2016/oct/24/difficult-breathe-inside-kolkata-india-rubbish-dumppermanently-fire

France-Presse \& Agence 2019. Garbage mountain at Delhi's Ghazipur landfill to rise higher than Taj Mahal by 2020 - India news - Hindustan Times. Retrieved January 8, 2020, from Hindustan Times website: https://www.hindustantimes.com/india-news/garbage-mountain-atdelhi-s-ghazipur-landfill-to-rise-higher-than-taj-mahal-by-2020/storyRC0kwZdUmdHHfDs3rJGngI.html

Goel, S. 2017. Solid and hazardous waste management : an introduction. In: Advances in Solid and Hazardous Waste Management, pp. 1-27. https://doi.org/10.1007/978-3-319-57076-1

Harshitha, V. and Nisar, M. 2019. Door-to-door collection of garbage in a mess | Deccan Herald. Retrieved June 19, 2019, from Deccan Herald website: https://www.deccanherald.com/city/bengaluru-infrastructure/ door-to-door-collection-of-garbage-in-a-mess-739969.html

Hazra, T. and Goel, S. 2009. Solid waste management in Kolkata, India: Practices and challenges. Waste Management, 29(1): 470-478. https:// doi.org/10.1016/j.wasman.2008.01.023

Hindu, T. 2012 July 7. Plastic waste chokes storm water drains. The Hindu. Retrieved from https://www.thehindu.com/news/plastic-waste-chokesstorm-water-drains/article3613373.ece 
Indore: Converting solid waste into electricity still a distant dream (n.d.). Free Press Journal. Retrieved October 8, 2018, from http:// www.freepressjournal.in/indore/indore-converting-solid-waste-intoelectricity-still-a-distant-dream/1185419

Jadhav, R. 2018. 75\% of municipal garbage in India dumped without processing | India News - Times of India. Retrieved June 20, 2019, from Times of India website: https://timesofindia.indiatimes.com/ india/75-of-municipal-garbage-in-india-dumped-without-processing/ articleshow/65190477.cms

Jank, A., Müller, W., Schneider, I., Gerke, F. and Bockreis, A. 2015. Waste separation press (WSP): A mechanical pretreatment option for organic waste from source separation. Waste Management, 39: 71-77. https:// doi.org/10.1016/j.wasman.2015.02.024

Karelia, G. 2019. Chennai store uses banana leaves to package veggies. Retrieved January 3, 2020, from The Better India website: https:// www.thebetterindia.com/179800/chennai-eco-friendly-shop-bananaleaf-packaging-india/

Kumar, S., Smith, S. R., Fowler, G., Velis, C., Kumar, S. J., Arya, S., Cheeseman 2017. Challenges and opportunities associated with waste management in India. Royal Society Open Science, 4(3). https://doi. org/10.1098/rsos.160764

Lahiry, S. 2017. India's challenges in waste management. Retrieved from http://www.downtoearth.org.in/blog/india-s-challenges-in-wastemanagement-56753

Lavania, D. 2018. Open garbage trucks litter Agra roads every day. Agra News - Times of India. Times of India. Retrieved from https:// timesofindia.indiatimes.com/city/agra/open-garbage-trucks-litter-cityroads-every-day/articleshow/62449605.cms

Lavasa, S. A., General, A., Secretary, M., Tiger, N., Authority, C. and Bonal, S. B. S. 2016. Press Information Bureau, Government of India, Ministry of Environment and Forests.

Lee, Y. Y., Jung, H., Ryu, H. W., Oh, K. C., Jeon, J. M. and Cho, K. S. 2018. Seasonal characteristics of odor and methane mitigation and the bacterial community dynamics in an on-site biocover at a sanitary landfill. Waste Management, 71: 277-286. https://doi.org/10.1016/j. wasman.2017.10.037

Malcolm Richard, G., Mario, M., Javier, T. and Susana, T. 2011. Optimization of the recovery of plastics for recycling by density media separation cyclones. Resources, Conservation and Recycling, 55(4): 472-482. https://doi.org/10.1016/j.resconrec.2010.12.010

Mandal, P. K. 2019. Review on evolution of municipal solid waste management in India : Practices, challenges and policy implications. Journal of Material Cycles and Waste Management, (0123456789). https://doi.org/10.1007/s10163-019-00880-y

Mandal, P., Chaturvedi, M. K., Bassin, J. K., Vaidya, A. N. and Gupta, R. K. 2014. Qualitative assessment of municipal solid waste compost by indexing method. International Journal of Recycling of Organic Waste in Agriculture, 3(4): 133-139. https://doi.org/10.1007/s40093014-0075-X

Manohar, M. 2017. Bhalswa landfill: Bhalswa landfill fire rages on as city chokes | Delhi News - Times of India. Retrieved September 27, 2018, from Times of India website: https://timesofindia.indiatimes.com/city/ delhi/delhi-pollution-bhalswa-landfill-fire-rages-on-as-city-chokes/ articleshow/61656243.cms

Manohar, M. 2019. Segregate waste at source or face Delhi corporation fines of up to Rs 1L. Times of India. Retrieved from https://timesofindia. indiatimes.com/city/delhi/segregate-waste-at-source-or-face-delhicorporation-fines-of-up-to-rs-1-lakh/articleshow/66278957.cms

Ministry of Housing and Urban Affairs. 2019. Solid waste management including hazardous waste, medical waste and e-waste twenty, 25th Report. Retrieved from http://164.100.47.193/lsscommittee/Urban Development/16_Urban_Development_25.pdf

Ministry of new and renewable energy, 2016. Standing committee on energy (2015-16) (Vol. 20)
Moghadam, M. R. A., Mokhtarani, N. and Mokhtarani, B. 2009. Municipal solid waste management in Rasht City, Iran. Waste Management, 29(1): 485-489. https://doi.org/10.1016/j.wasman.2008.02.029

Nagendra, B., Lakshmisha, A. and Agarwal, P. 2019. Mobile application in municipal waste tracking: a pilot study of "PAC waste tracker" in Bangalore city, India. Journal of Material Cycles and Waste Management, 21(3): 705-712. https://doi.org/10.1007/s10163-01800819-9.

Padilla, J.A. and Trujillo, J. C. 2017. Waste disposal and households' Heterogeneity. Identifying factors shaping attitudes towards sourceseparated recycling in Bogotá, Colombia. Waste Management, 74: 16-33. https://doi.org/10.1016/j.wasman.2017.11.052.

Pandey, S. and Malik, J. K. 2015. Industrial and Urban Waste Management in India. The Energy and Resources Institute.

Planning Commission, 2014. Report of the Task Force on Waste to Energy (Volume I ): In the context of Integrated Municipal Solid Waste Management. In Task Force on Waste to Energy. Retrieved from http://planningcommission.nic.in/reports/genrep/rep_wte1205.pdf

Press Trust of India Ltd. 2019. Lack of waste management in Bihar can lead to emergency-like situation: NGT | Delhi News - Times of India. Times of India. Retrieved from https://timesofindia.indiatimes. com/city/delhi/lack-of-waste-management-in-bihar-can-lead-toemergency-like-situation-ngt/articleshow/68524020.cms

Priya, L. 2019. Going green: Kerala moots banana leaves as plastic-free food wrappings - the better India. Retrieved January 3, 2020, from The Better India website: https://www.thebetterindia.com/169650/ kerala-green-packing-banana-leaves-food-parcel/

Pulat, H. F. and Yukselen-Aksoy, Y. 2017. Factors affecting the shear strength behavior of municipal solid wastes. Waste Management. https://doi.org/10.1016/j.wasman.2017.08.030

Rai, S. 2017. Making the best out of waste: These 8 startups are helping Indian cities manage trash. Retrieved July 16, 2019, from Your Story website: https://yourstory.com/2017/11/waste-management-startups

Rajkumar, J. and Sirajuddin, A. 2016. Status and challenges of municipal solid waste management in India : A review. Cogent Environmental Science, 2(1): 1-18. https://doi.org/10.1080/23311843.2016.1139434

Rawat, M., Ramanathan, a L. and Kuriakose, T. 2013. Characterisation of municipal solid waste compost ( MSWC ) from selected Indian cities-a case study for its sustainable utilisation. Journal of Environmental Protection, 4: 163-171. https://doi.org/10.4236/jep.2013.42019

Sambyal, S. S. and Agarwal, R. 2018. Forum of cities that segregate. In: Assessment Report 2017-18. Retrieved from https://www.cseindia. org/model-framework-for-segregation-8603

Sharholy, M., Ahmad, K., Mahmood, G. and Trivedi, R. C. 2008. Municipal solid waste management in Indian cities - A review. Waste Management, 28(2): 459-467. https://doi.org/10.1016/j. wasman.2007.02.008

Sharma, N. 2018. Dehradun, Haridwar ULBs flout waste disposal rules, says CAG | Dehradun | Hindustan Times. Retrieved June 18, 2019, from Hindustan Times website: https://www.hindustantimes.com/ dehradun/dehradun-haridwar-ulbs-flout-waste-disposal-rules-sayscag/story-Dqfbt0GkL42Ogpjg7HG46J.html

Shwetmala, Chanakya, H. and Ramachandra, T. 2011. ICON SWM 2011 2nd International conference on solid waste management and exhibition Assessment of solid wastes choking open sewers and vulnerability to urban flooding. Retrieved from http://wgbis.ces.iisc. ernet.in/energy/paper/iconswm_urban_flooding/ufsw.pdf

Smart City Indore (n.d.). Solid Waste Management. Retrieved June 24, 2019, from https://www.smartcityindore.org/solid-waste/

Speier, C. J., Nair, R. R., Mondal, M. M. and Weichgrebe, D. 2019. Multi-sector evaluation of generation, composition and sustainable treatment systems for commercial waste streams in India. Journal of Material Cycles and Waste Management, (0123456789). https://doi. org/10.1007/s10163-019-00869-7 
Subramanian, A. 2017. At this ATM, deposit garbage to withdraw rewards - the better India. Retrieved May 21, 2019, from The better India website: https://www.thebetterindia.com/95751/garbage-wastesegregation-atm/

Sujauddin, M. 2008. Household solid waste characteristics and management in Chittagong, Bangladesh. Waste Management, 28: 1688-1695. https:// doi.org/10.1016/j.wasman.2007.06.013

Swachh Survekshan 2018 Results: Top 10 Highlights (n.d.). Retrieved August 23, 2019, from https://swachhindia.ndtv.com/swachhsurvekshan-2018-top-10-highlights-19749/

The Curious Case of a Clean Clean Indore- Business News (n.d.). Retrieved June 24, 2019, from https://www.businesstoday.in/magazine/columns/ the-curious-case-of-a-clean-clean-indore/story/254144.html

The World Bank, 2018. Data Catalog. Retrieved June 27, 2019, from The World Bank website: https://datacatalog.worldbank.org/dataset/whatwaste-global-database

TNN, 2018. Ghazipur: Fire at Ghazipur landfill, more expected as mercury rises | Delhi News - Times of India. Retrieved September 27, 2018, from Times of India website: https://timesofindia.indiatimes.com/ city/delhi/fire-at-ghazipur-landfill-more-expected-as-mercury-rises/ articleshow/63372938.cms

Tonini, D., Albizzati, P. F. and Astrup, T. F. 2018. Environmental impacts of food waste: Learnings and challenges from a case study on UK. Waste Management, 76: 744-766. https://doi.org/10.1016/j. wasman.2018.03.032

Vibha Sharma and Snehal Tripathi, 2017. Four months on, garbage segregation at source still not doable for Delhi residents | delhi news | Hindustan Times. Retrieved June 15, 2019, from Hindustan Times website: https://www.hindustantimes.com/delhi-news/four-monthson-garbage-segregation-at-source-still-not-doable-for-delhi-residents/ story-NxOX21QqAfDmiR3OZmE0RJ.html

Woodford, C. 2019. Plasma arc waste recycling - A simple introduction. Retrieved January 21, 2020, from Expalinthatstuff.com website: https:// www.explainthatstuff.com/plasma-arc-recycling.html

Yaqoob, M. 2018. Much-hyped waste segregation at source non-starter, Greater Kashmir. Retrieved June 15, 2019, from Greaterkasmir.com website: https://www.greaterkashmir.com/news/srinagar/much-hypedwaste-segregation-at-source-non-starter/ 